\title{
Multiple detachments during thin-skinned deformation of the Swiss Central Jura: a kinematic model across the Chasseral
}

\author{
Marc Schori $^{1} \cdot$ Jon Mosar $^{1} \cdot$ Guido Schreurs $^{2}$
}

Received: 16 February 2015/Accepted: 13 August 2015/Published online: 9 September 2015

(C) Swiss Geological Society 2015

\begin{abstract}
Combining field observations, cross-section area balancing techniques and kinematic forward modelling, we present new insights into the evolution of the Jura fold-and-thrust belt in the Chasseral area between Lake Biel and the Vallon de St-Imier, in the Canton of Bern, Switzerland. Our results show that the structures of the Chasseral area and the associated regional uplift can be explained by thin-skinned deformation of the Mesozoic cover, without the need to involve highs in the pre-Triassic basement or invoking detachment folding with thickening of anticlinal cores by flow of Triassic evaporites. According to our thin-skinned model, the overall structure of the Chasseral initiated as a large-scale fault-bend fold, with initial detachment of the Mesozoic cover and NNW-directed movement of material along a basal décollement in Middle Triassic evaporites and important displacement along an upper detachment in the Middle Jurassic Opalinus-Ton Formation. This upper detachment extends from the Seekette to the Vallon de St-Imier (at least $11 \mathrm{~km}$ ) and further to the north. Deformation above the upper detachment occurs to the north of the Chasseral area and steps back later to form a series of forward-stepping fault-
\end{abstract}

Editorial handling: S. M. Schmid.

Electronic supplementary material The online version of this article (doi:10.1007/s00015-015-0196-x) contains supplementary material, which is available to authorized users.

Marc Schori

schori@cubenet.ch

1 Department of Geosciences, Université de Fribourg, Chemin de musée 6, 1700 Fribourg, Switzerland

2 Institut für Geologie, Universität Bern, Baltzerstrasse 1+3, 3012 Bern, Switzerland propagation folds at the northern Chasseral mountainside, with associated thrusts that show a typical stair-step geometry due to low-angle breakthroughs. The Seekette anticline on the southern Chasseral mountainside formed due to a late back-stepping backthrust. A total displacement of $11.3 \mathrm{~km}$ is inferred that considerably exceeds a displacement estimation of $5.1 \mathrm{~km}$ deduced from shortening of the upper boundary of the Jurassic sequence. Forward modelling suggests that material was transported $6.2 \mathrm{~km}$ along the Opalinus-Ton detachment resulting in complex deformation to the north of the Vallon de St-Imier because there, folds and thrusts formed above both, the upper detachment and the basal décollement and interacted together.

Keywords Jura Mountains - Tectonics - Basal décollement · Forward modelling - Trishear kinematic model

\section{Introduction}

Although the Jura Mountains have been intensely studied since the nineteenth century, a modern kinematic structural framework is lacking for large parts. Nevertheless, geological and geophysical data for the Swiss Molasse Basin (SMB) and the Jura Mountains have been collected over the past decades by oil, gas and water prospection or construction projects such as railway tunnels. A number of seismic lines, drill-cores, surface data and interpreted geological cross-sections are at hand, although irregularly distributed geographically. There are many seismic lines for the SMB (Sommaruga et al. 2012) and a fairly dense network of lines also exists for the Swiss Central Jura west of Lake Biel (Sommaruga 1997; Sommaruga et al. 2012, 


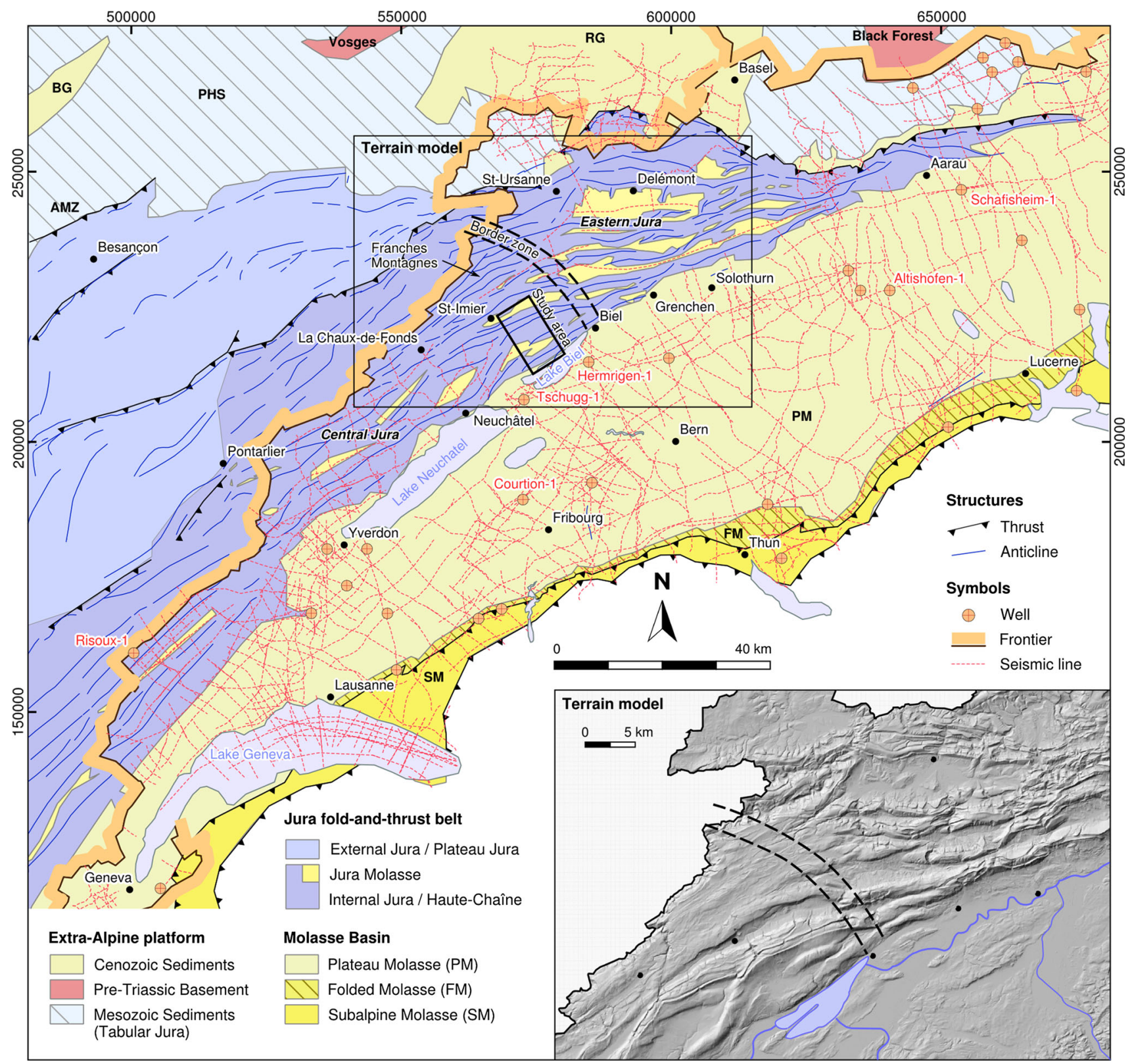

Fig. 1 Geological overview map centred on the Swiss Jura Mountains. Geological units, traces of anticlines in the Jura and thrusts are from Swisstopo (2005). The map indicates most deep-wells in the Molasse basin and seismic lines, acquired between 1930 and 1999 (Sommaruga et al. 2012). The stippled lines mark the border zone between Eastern and Central Jura as used herein. The hill shade figure

Fig. 1). Deep-wells in Switzerland were primarily drilled within the SMB and in the Tabular Jura but only one relevant well, the Risoux-1 well (Winnock 1961) in Western Switzerland lies in the Internal Jura (Fig. 1). The SMB deep-well Courtion-1 (Canton Fribourg, Fischer and Luterbacher 1963) revealed disturbed Triassic evaporite sequences and Jordan (1992) identified important shear zones in the Triassic sequence of the SMB deep-wells derived from the digital terrain model (Swisstopo 2011) in the bottom right corner illustrates the difference in geomorphology between Eastern and Central Swiss Jura. The rectangle indicates the study area. $B G$ Bresse Graben, $A M Z$ Avant-Monts Zone, PHS Plateau de Haute-Saône, $R G$ Rhine Graben

Schafisheim-1 and Altishofen-1 in the hinterland of the Eastern Jura Mountains. These observations suggest a decoupling of the Mesozoic cover in the Triassic evaporites. The resolution of seismic lines at the base of the Mesozoic sequence, especially beneath the Jura Mountains, is not sufficient to unambiguously identify structures that show the interaction between the basement and the sedimentary cover (Guellec et al. 1990; Sommaruga 1999). 
At the beginning of the twentieth century, Buxtorf (1907, 1916) suggested a large-scale basal décollement of the Alpine foreland in the Triassic evaporites, above which the deformation of the Jura Mountains took place, based on observations in railway tunnels and because he realized that no strata older than Triassic in age are exposed in the Jura Mountains. The SMB, pushed by the Alps, slid as an only weakly deformed and basically intact unit on the décollement in the Triassic sequence, and transferred the deformation to the NW (Buxtorf 1916). This concept of the Alpine foreland is often referred to as Distant Alpine Push (in German: Fernschub) hypothesis (Buxtorf 1916; Laubscher 1961). Deformation restricted to the sedimentary cover above the detachment level is frequently referred to as thin-skinned deformation.

Since the introduction of the concepts of balanced crosssections and critically tapered wedges, and given the availability of new data from deep wells, most geologists have accepted a continuous basal décollement underneath the Alpine foreland within the Triassic evaporites (Laubscher 1961; Burkhard 1990; Guellec et al. 1990; Jordan 1992; Sommaruga 1997; Becker 2000). The thin-skinned deformation stage is considered to have started no earlier than in Serravallian times (Middle Miocene) and to have ceased in Early Pliocene times (Laubscher 1992; Becker 2000). Guellec et al. (1990) proposed a transition to thick-skinned deformation involving basement thrusts underneath the foldand-thrust belt, which followed the thin-skinned deformation stage, to explain a basement high interpreted in a seismic line crossing the Internal Jura at Champfromier (to the west of Geneva in France). Jordan (1992) argued that some Early Triassic grabens and depressions, filled with halite deposits of the Anhydritgruppe Formation, were extruded due to Late Tertiary basin inversion, in order to explain convex salt cushions interpreted on seismic lines across the SMB.

Also in the external parts of the Jura many recent studies indicated a late transition (post-early Pliocene) to thickskinned tectonics (Mosar 1999). Madritsch et al. (2008) proposed active thick-skinned neotectonics since post-early Pliocene times, connected with the Rhine-Bresse Transfer Zone, in the Besançon area and the Avant-Monts Zone (eastern France, Fig. 1), deduced from recent seismicity and seismic reflection data. Ustaszewski and Schmid (2006, 2007) reported the reactivation of pre-existing basement faults in Late Pliocene times, based on seismic lines and structural contour maps, in the northernmost part of the Jura at the southern Rhine Graben. Similarly, Becker (2000) interpreted a transition to thick-skinned and on going neo-tectonics in the Alpine foreland, derived from in situ stress measurements in boreholes at the Jura Mountains, which show that recent stress fields are in poor accordance with paleo-stress associated with the formation of the Jura Mountains.
The presence of regional structural uplifts in the Jura has been frequently used in favour of models that include basement highs associated with thick-skinned tectonics (e.g. Guellec et al. 1990; Pfiffner et al. 1997). Although thick-skinned deformation before and after the main thinskinned deformation stage undoubtedly occurred in certain restricted places, this study aims to show that regional structural uplift and uplift of the plateaus in the Jura (e.g. Plateau de Diesse) could also have been produced during the main thin-skinned deformation, without invoking subsequent thick-skinned reactivations. We present a comprehensive structural study of the Chasseral area with the aim of improving our understanding of the main undoubtedly thin-skinned stage of deformation in the Swiss Central Jura Mountains. Thereby we discuss a viable thinskinned deformation style using cross-section balancing techniques and kinematic forward modelling, and we highlight vital structural consequences.

\section{Geological setting}

The Jura Mountains extend from Northern and Western Switzerland to eastern France (Fig. 1). The arc shaped Jura Mountains fold-and-thrust belt comprises the Internal Jura (Haute-Chaîne) and the External Jura (Plateau Jura), where wide synclinal areas ("Plateaux") are separated by narrow compression belts ("Faisceaux", Swisstopo 2005). The Tabular Jura lies north of the Eastern and Central Jura. It does not belong to the fold-and-thrust belt proper and only comprises autochthonous Mesozoic cover of the southern Black Forest and Vosges basement (Sommaruga 1997). The Chasseral area, in between Lake Biel and the Vallon de St-Imier (Fig. 2), belongs to the southernmost part of the Central Internal Jura. The southern Jura Mountains are the most deformed (highest chains), while northern parts are less deformed with a total shortening over the Central Jura of $25 \mathrm{~km}$ and more (Burkhard 1990). The Jura has been classically seen as forward propagating fold-andthrust belt but this is far from being generally accepted. Smit et al. (2003) showed by means of analogue modelling that the thrust-sequence depends on the basal wedge angle, the shortening rate and the coupling between the basement and the cover, and comparison with analogue models rather suggests that the sequence in the Jura is non-frontward.

The geomorphology is somewhat different in the eastern and central part of the Jura. In the Eastern Jura fold axes generally trend ENE-WSW, whereas they are more NESW oriented in the Central Jura (Fig. 1). The border zone between Eastern and Central Jura lies close to the city of Biel. The Jura to the east of Biel shows notably more consecutive mountain chains and deep valleys that are filled with Molasse deposits (Fig. 1). In contrast, the Internal 


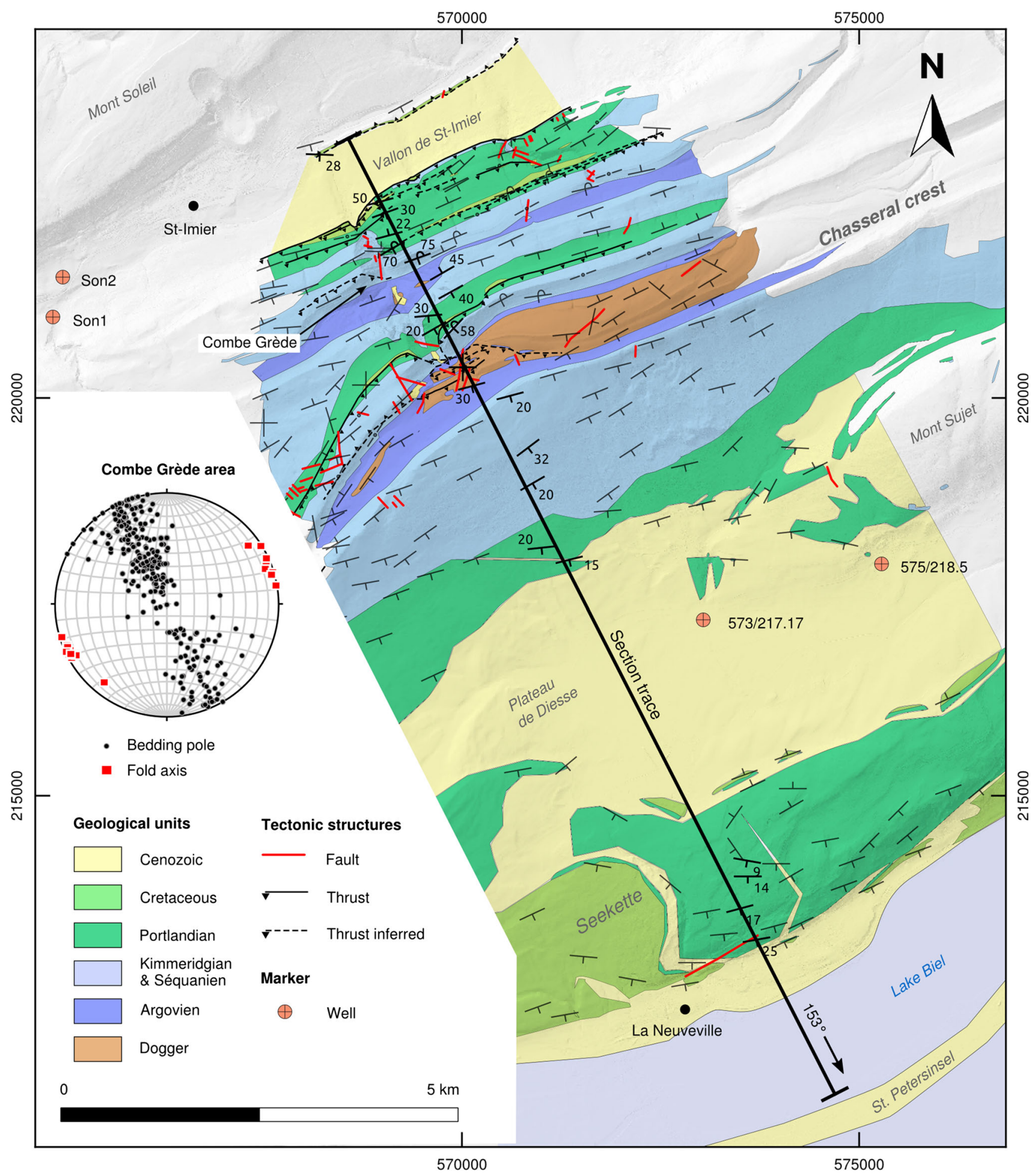

Fig. 2 Overview of the Chasseral area. Geological units are modified from the swisstopo GeoCover (Swisstopo 2012) and the Geological Atlas 1:25000 (Schär et al. 1971) and overlie a hillshade model (Swisstopo 2011) that illustrates the topography of the terrain. Dip data is taken from Swisstopo (2012). The oldest exposed geological units belong to the upper Dogger sequence. Traces of faults and thrusts are from Schori (2014). The lower hemisphere equal-area projection shows bedding poles and fold axes for the northern Chasseral mountainside at the Combe Grède (Schori 2014) 
Central Jura has fewer consecutive mountain chains and more elevated plains in between, such as the Plateau de Diesse north of Lake Biel (Fig. 2) or the Franches Montagnes between Delémont and La Chaux-de-Fonds (Fig. 1). Remarkably, the Eastern Jura exclusively consists of the Haute-Chaîne structural zone and lacks the external part with plateaus such as known from the Central Jura. These differences stress the need for a separate examination of each domain and show that structural studies in the Eastern Jura may not apply to the Central Jura. Previous studies in the Eastern Jura are found in Laubscher (1986), Bitterli (1992), Noack (1995) and Laubscher (2008), and additionally in reports of the National Cooperative for the Disposal of Radioactive Waste (Nagra). The Central and Western Jura Mountains were extensively studied by Philippe (1995), Sommaruga (1997) and Affolter (2003).

\section{Methods}

\subsection{General procedure}

Based on available surface data (Fig. 2), a well constrained cross-section of the Chasseral area was constructed as a first working basis, showing the extent of exposed lithological horizons. Subsequently this section was analysed using state of the art balancing techniques, which benefited from substantial developments in the past decades. There is an impressive palette of techniques (see Laubscher 1965; Suppe 1983; Mitra and Namson 1989; Suppe and Medwedeff 1990; Erslev 1991; Epard and Groshong 1993; Allmendinger 1998). These allow the inference of structures at depth based on surface observations. A key balancing technique that was used to define the main structural style at depth is based on excess area (Mitra and Namson 1989; Epard and Groshong 1993). A kinematic forward model of the Chasseral area was worked out during a second step, using fault-bend fold and fault-propagation fold concepts (Suppe 1983; Suppe and Medwedeff 1990) and implemented according to the trishear kinematic model (Erslev 1991; Allmendinger 1998). In this way the initial working basis cross-section was interpreted at depth and the construction of horizons exposed at the surface was improved in a step-by-step kinematic approach.

\subsection{Fold and thrust related terms}

The term "branch point" refers to the location at which a thrust branches off the detachment horizon, or, more generally, where one thrust branches off another in a crosssection (Fig. 3). The angle between a foreland verging thrust (the ramp) and a detachment (the flat) is commonly between $20^{\circ}$ and $30^{\circ}$. The bisector trajectory of a thrust-
Fault-propagation fold (High-Angle breakthrough)

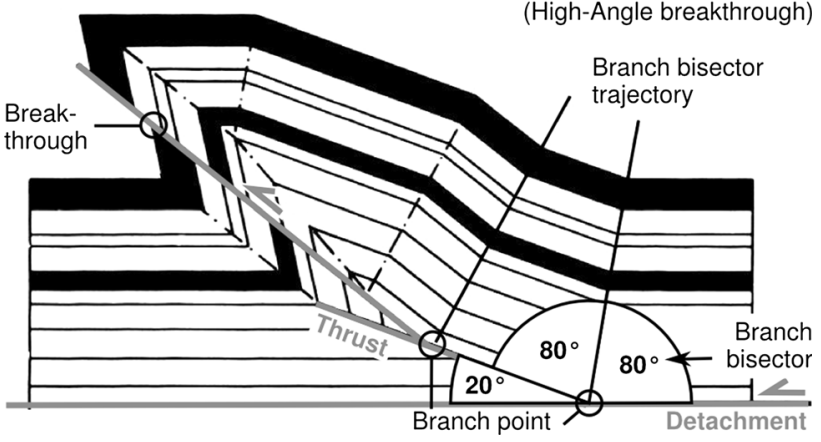

Fig. 3 Fault-propagation fold adapted from Suppe and Medwedeff (1990). The drawing illustrates the terms which were used to describe fold and thrust related geometrical aspects

branch refers to the bisector of the obtuse angle $\left(150^{\circ}-\right.$ $160^{\circ}$ ), which is formed between the thrust and the fault from which the thrust branches off. The term "fault-breakthrough" (Suppe and Medwedeff 1990) describes a thrust, which cuts through the front of a fault-propagation fold.

\subsection{Excess-area graphical technique}

Area conservation principles to balance cross-sections were first applied by Chamberlin (1910, 1919). Since then, different area balancing methods were frequently used to validate cross-sections (see summary in Mitra and Namson 1989). The excess-area graphical technique (Epard and Groshong 1993) used hereafter allows to determine the principal structural style (fault-bend folding vs. detachment folding or fault-propagation folding) and to examine alternatives in the construction of cross-sections (Epard and Groshong 1993). This technique is well suited to analyse the data available for the Chasseral area.

The fault-propagation and detachment fold concepts describe a detachment above which shortening leads to tectonic uplift of material, commonly quantified with excess areas (S) underneath a folded lithological reference horizon (Fig. 4). The excess-area graphical technique (Epard and Groshong 1993) plots the excess area (S) and height (h) of each horizon in an area-height diagram, whereupon ideally all data points lie on a straight line (Fig. 4a). The graphical construction leads to the total displacement (D) and the depth of the detachment $\left(\mathrm{h}_{0}\right)$, in case of a detachment fold or fault-propagation fold (Fig. 4b). The situation has to be reconsidered for faultbend folds (Suppe 1983), where material transport occurs along an upper detachment with the height $h_{u}$ (Fig. 4c). The displacement on the upper flat (d) transports material horizontally past the pin line at the fold front (Fig. 4d). The loss of area $\left(\Delta \mathrm{S}_{2}\right)$ beyond the pin line reduces the slope of the resulting graph in the area-height diagram, for horizons 


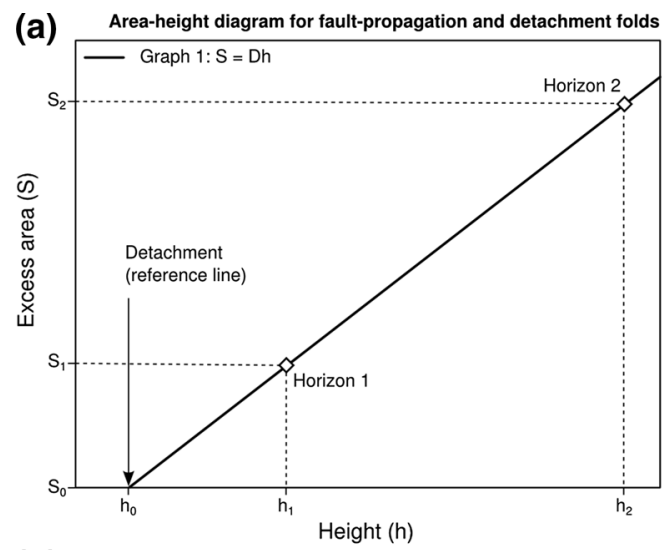

(b)

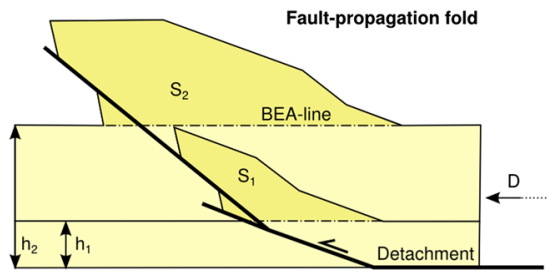

Fig. 4 Illustration of the excess-area graphical technique for different fold types. a Area-height diagram for fault-propagation and detachment folds with the detachment as reference level. b Fault-propagation fold sketch adopted from Suppe and Medwedeff (1990). c Areaheight diagram for fault-bend folds with the lower detachment as reference level and $\mathbf{d}$ corresponding schematic diagram of a fault-

above the upper detachment (Fig. 4c). With a known position of the lower and upper detachment, the total displacement (D) of fault-bend folds, represented by the slope of the steeper graph (Fig. 4c), can be determined.

\subsection{Kinematic forward modelling}

\subsubsection{Tools}

The subsequently presented forward model was created with the structural modelling software Move 2014.2, developed by Midland Valley Ltd. The software contains a 2D Move-on-fault module that supports various methods to model thrusts and folds. We modelled fault-propagation folds using the trishear kinematic model (Erslev 1991; Allmendinger 1998) that permits forward modelling of cross-sections by maintaining constant total areas, but the thickness of stratigraphic units may still vary locally. The concept of the trishear kinematic model is such that a triangular zone of deformation (trishear zone) migrates through the section, at the tip of a growing fault. Trishear has to be applied numerically and the distortion within the trishear zone is calculated to match observed fold shapes. The software uses a fault-parallel flow algorithm (Egan et al. 1997; Kane et al. 1997) to model deformation that occurs outside of the trishear zone. Fault-parallel flow

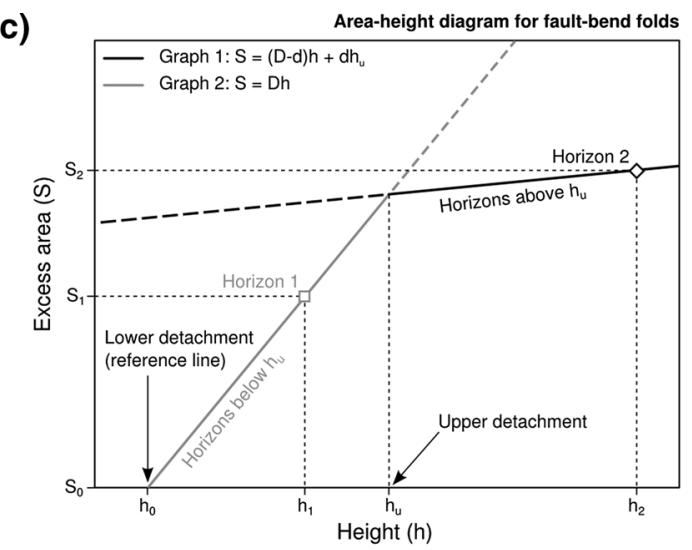

(d)

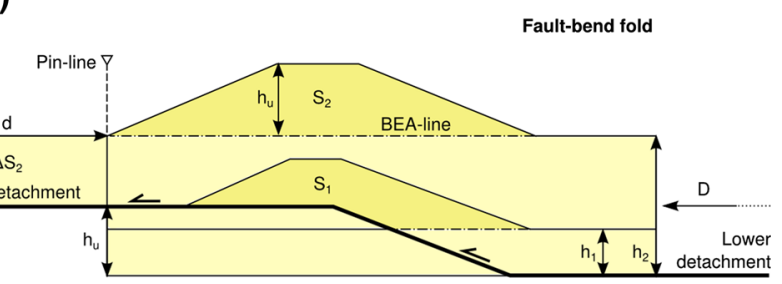

bend fold (Epard and Groshong 1993 after Mitra and Namson 1989). The base excess-area (BEA) construction lines are indicated with dash-dot lines. $D$ total displacement, $d$ displacement across the pin line, $h_{u}$ ramp height, $h_{1}$ height of horizon $1, h_{2}$ height of horizon $2, S_{l}$ excess area underneath horizon $1, S_{2}$ excess area underneath horizon 2, $\Delta S_{2}$ area which moved past the pin line

moves material particles in the hanging wall along flow paths, which are parallel to the fault surface. Several forward models were tested and only the most accurate model is presented here. An animated version of this forward model is provided in Online Resource 1. A first solution showing the thrust trajectories across undeformed beds was achieved by unfolding field-constrained horizons in a working basis cross-section. This step was performed with the Unfolding module of the structural modelling software, using the "Line length" method. However, the positions of branch points were refined afterwards, when the forward model was worked out and improved in a step-by-step approach.

\subsubsection{Default structural style}

The applied forward modelling technique grants a wide degree of freedom owing to its non-physical nature and therefore it is crucial to make use of a default structural style (Laubscher 2003, 2008), defined by assumptions and observations with a physical background. Here the default structural style is defined as follows: (1) the folds of the Haute-Chaîne were initiated with a detachment in the Triassic anhydrites and they developed into fault-propagation and fault-bend folds after the outbreak of thrusts (Sommaruga 1999). (2) The top of the basement has a 
general dip of $\sim 2.5^{\circ}$ to the SSE (Laubscher 2003). (3) There are foreland-verging as well as hinterland-verging thrusts (Bitterli 1992; Sommaruga 1999). (4) Forelandverging thrusts typically show at least kilometric dip-slip; their ramps dip between $20^{\circ}$ and $30^{\circ}$ or more and thrustbreakthroughs occur frequently (Sommaruga 1999). (5) Hinterland-verging thrusts are considered as backthrusts with small displacements in the order of a few meters up to hundreds of meters (Sommaruga 1999). Backthrusts are steeper than foreland-verging thrusts with mean dips of $37^{\circ}$ (defined for the Eastern Jura in Bitterli 1992). (6) Molasse sediments were deposited pre- and syn-tectonically, in the Molasse Basin, as well as in the Vallon de St-Imier (Mosar et al. 2008).

\subsubsection{Simplifications}

The section trace crosses several strike-slip faults with relatively small offsets up to $100 \mathrm{~m}$ (Fig. 2), especially in the Chasseral anticline forelimb. Lateral displacement of material makes the $2 \mathrm{D}$ balancing very problematic. Therefore, the presented forward model simplifies the Chasseral area in respect of strike-slip faults. They are ignored in order to be able to use 2D balancing techniques. This is regarded as justified since the strike-slip faults only have minor offsets and therefore do not significantly modify the major structure. Furthermore, the forward model simplifies the initial state of Mesozoic units by assuming that all beds had constant thickness over the entire area. Also, the exact topography of the basement is not known since there are no seismic lines across the study area. The model hence assumes a flat basement topography. Note that we use "basement" s.l., which includes Early Triassic sediments present in depressions of the Pre-Triassic basement, as well as continental sediments in Permo-Carboniferous troughs that may exist below the Triassic detachment horizon. The focus of the forward model was on resolving the principal aspects and geometries of the Chasseral area large-scale structure. We therefore did not take into account the many short wavelength folds present at the northern Chasseral mountainside. Note that the trishear kinematic model does not depend on mechanical properties of rocks; it provides no more than a bulk kinematic description of a deformed area (Allmendinger 1998) and it does not describe in which way the strain was accommodated (e.g. by brittle or ductile deformation processes).

\section{Stratigraphy}

In order to construct a cross-section that defines the endstate of the forward model, it was necessary to establish a locally valid stratigraphic column that includes the thickness of the Mesozoic units. The Seismic Atlas of the Molasse Basin (Sommaruga et al. 2012) includes seismic line interpretations over the whole SMB, which are depth converted and calibrated with deep-wells, such as the Hermrigen-1 (Housse 1982; Fornage 1983) and Tschugg-1 well (Schlanke et al. 1978) located close to the study area (Fig. 1). The Seismic Atlas furthermore contains a 3D model, which is based on the depth converted seismic interpretations. The model is provided in the form of digital depth grids illustrating the 3D extent of important horizons. The published version of the Seismic Atlas uses smoothed depth grids. Here we use the original and unsmoothed depth grids (Engler and Sommaruga 2013) in two different ways. First, the SSE end of our cross-section overlaps with the grids, between the St. Petersinsel and La Neuveville (Fig. 2), and therefore the intersections between depth grids and the section could be used to define the extent of Mesozoic sequences underneath Lake Biel. Secondly, the grids were used to calculate the thicknesses of Mesozoic units below the Séquanien sequence (Fig. 5) at the SSE end of the section (CH1903/LV03 576035 211909). The thickness of the Opalinus-Ton Formation is taken from descriptions of the Hermrigen-1 well (Fornage 1983) and the thickness of the Wellengebirge and Buntsandstein Formation from the Schafisheim-1 drilling-core (Thurry and Amman 1990).

Lithological thicknesses of the uppermost units above the Argovien sequence correspond to values estimated for the northern Chasseral mountainside at the Combe Grède. There, the Argovien sequence appears to be thinned to about 95-115 m (Schori 2014), whereas it is estimated to $202 \mathrm{~m}$ at the SSE end of the section trace (from unsmoothed grids of Engler and Sommaruga 2013). The tectonically undisturbed thickness of $202 \mathrm{~m}$ is assumed to correspond to the initial thickness after deposition and was used for creating the forward model.

\section{Working basis cross-section}

\subsection{Field-constrained horizons}

The cross-section of Fig. 6 shows the geological interpretation of structures on the southern Chasseral mountainside based on the Geological Atlas 1:25000, map sheet Biel 1145 (Schär et al. 1971). On the northern Chasseral mountainside, where fold-and-thrust structures are notably more complex, field studies and remote sensing analysis provide a dense set of surface data (see Fig. 2 and Online Resource 2) and supplement geological data from the swisstopo GeoCover (Swisstopo 2012). Mesozoic geological units exposed in the Chasseral area were deposited between Late Middle-Jurassic and Early Cretaceous times 
Fig. 5 Compiled stratigraphy of the Mesozoic cover. Thicknesses of units above the Argovien sequence are estimated for the Combe Grède area (Schori 2014), whereas thicknesses of older units are based on unsmoothed depth grids of Engler and Sommaruga (2013) at CH1903/LV03 $576035211909 . h_{u}, h_{1-5}$ height of important horizons above the basal décollement $\left(\mathrm{h}_{0}\right)$
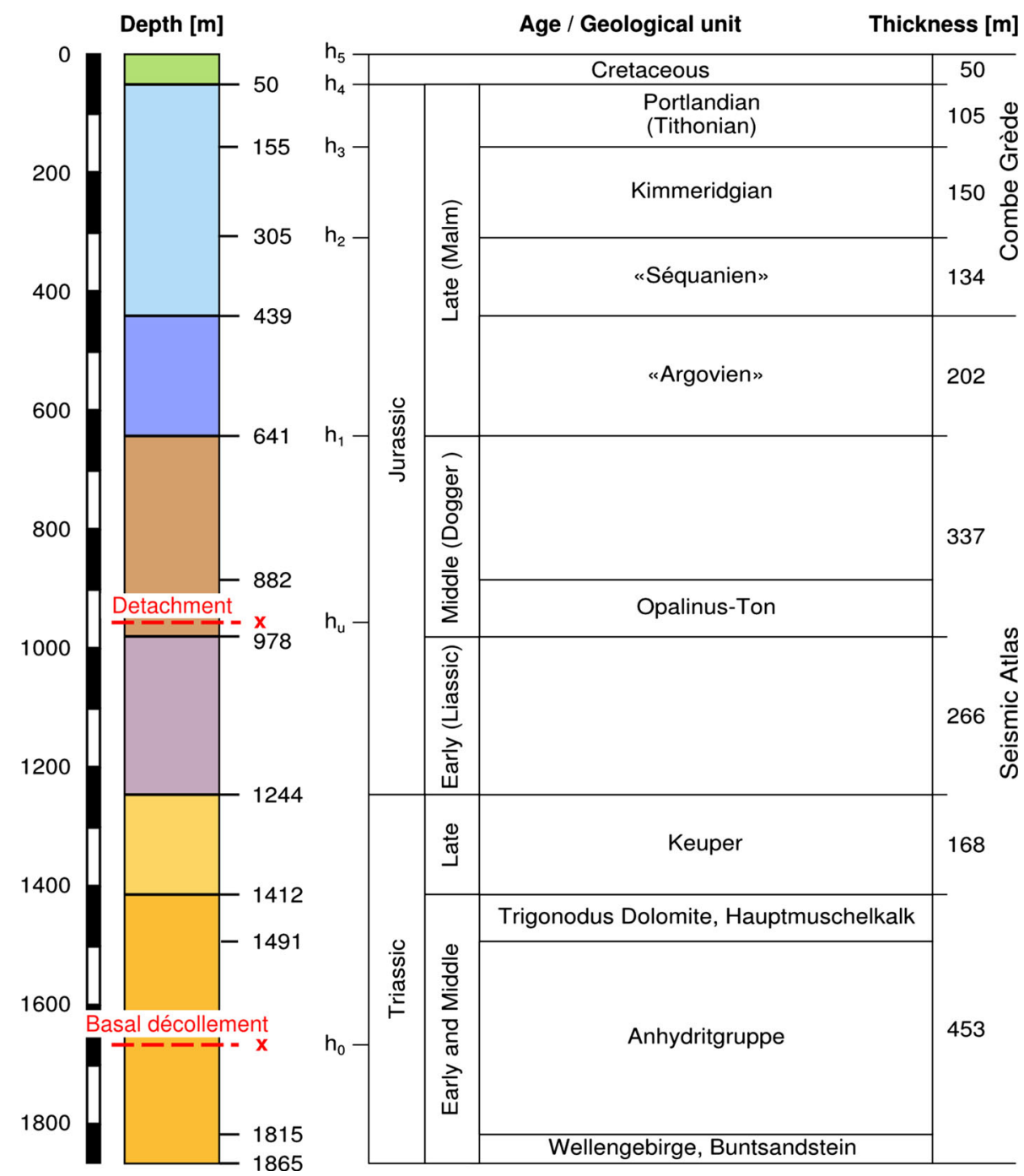

(Fig. 5). The extent of these field-constrained units was mostly constructed from the available surface data. The depth and extent of the upper Mesozoic Formations in the Vallon de St-Imier is known from combined seismic and drill-core investigations (Della Valle et al. 1998). The extent of the upper Mesozoic sequence beneath the Plateau de Diesse is known from boreholes close to the section trace (Fig. 2), obtained by the Amt für Wasser und Abfall (AWA) of the Canton of Bern, indicating the presence of a large open syncline beneath Molasse and Quaternary sediments (Fig. 6). At the margin of the Molasse Basin, beneath Lake Biel, the extent of Mesozoic lithological units is indicated by interpolated and unsmoothed depth grids of Engler and Sommaruga (2013). The cross section was constructed along an azimuth of $153^{\circ}$, perpendicular to regional and local fold axis orientations (Fig. 2) and thus parallel to the inferred regional transport direction. Prior studies, which also contain cross-sections across the Combe Grède, are found in Lüthi (1954) and Persoz and Burkhard (2006).

\subsection{Deep structures}

The basal décollement of the cover in the Alpine foreland cannot be viewed as a discrete plane, but rather represents a broad zone containing several detachments. Jordan (1992) observed several detachment zones in the Middle Triassic Anhydritgruppe, and additionally some smaller ones in the Gipskeuper. He noted that the "... main shear movements are concentrated within distinct (often relatively thin) horizons...". As it is not possible in practice to forward model several parallel detachment zones effectively, we chose the centre of the Anhydritgruppe Formation, $200 \mathrm{~m}$ above the base of the Mesozoic sequence (Fig. 5) as a proxy for the stratigraphic level along which the basal décollement occurred (Fig. 6). This level lies approximately in the centre of the basal décollement zone within the Anhydritgruppe Formation. This keeps the error resulting from reducing the zone to a discrete plane to a minimum. 


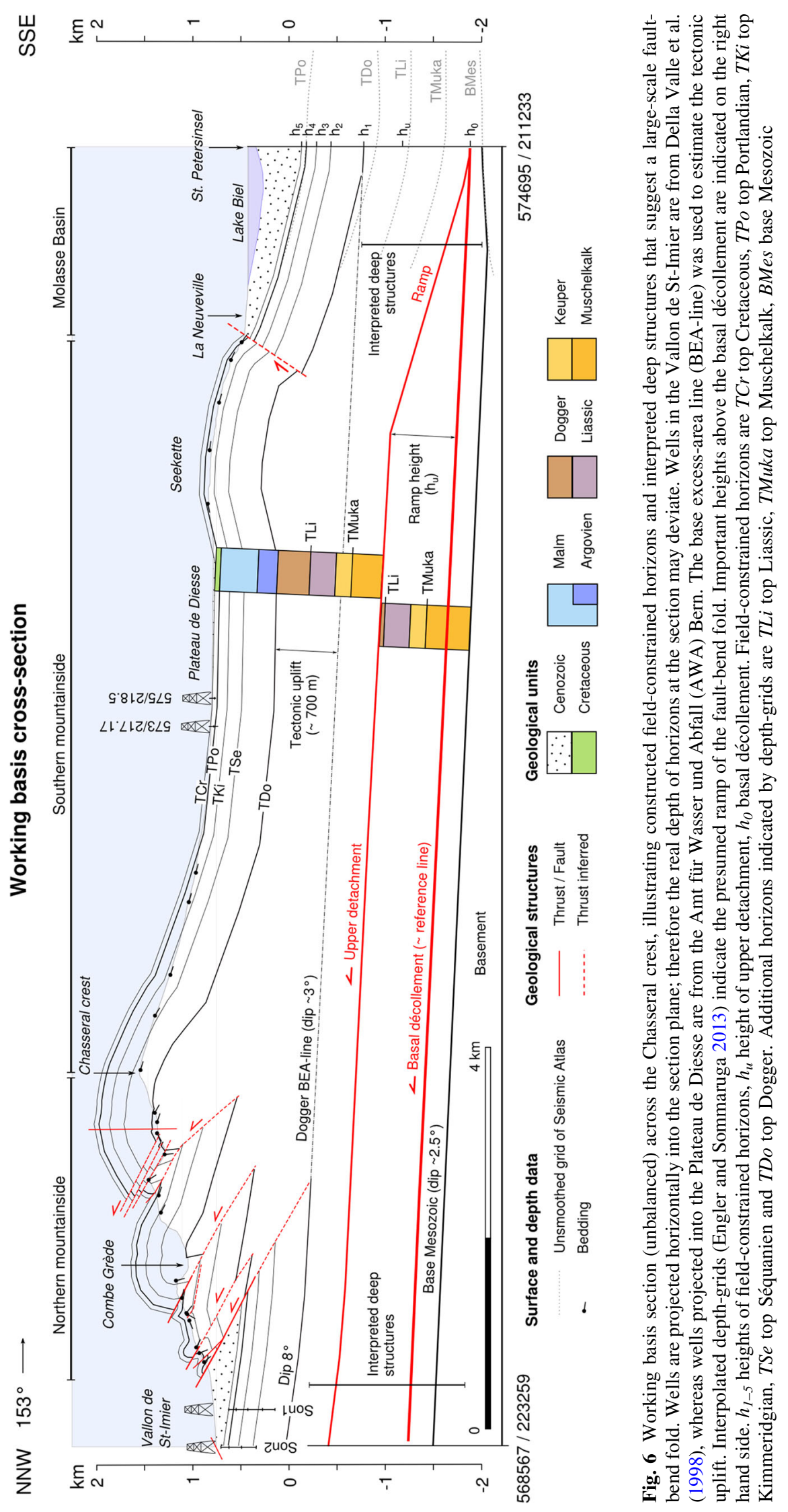


In order to evaluate the principal structure (fault-bend fold vs. detachment anticline or fault-propagation fold, respectively) of the working basis cross-section (Fig. 6), the excess-area graphical technique was applied. The reference line $\left(\mathrm{h}_{0}\right)$ was set at the defined basal décollement level in the SSE of the cross-section (Fig. 6). The tops of field-constrained Mesozoic units (Cretaceous, Portlandian, Kimmeridgian, Séquanien and Dogger sequences) were used for the construction of the area-height diagram graph. The heights $\left(\mathrm{h}_{1-5}\right.$, Fig. 6) above the reference line were calculated from stratigraphic thickness (Fig. 5). The base of excess-area lines (BEA-lines) was constructed by connecting identical horizons beneath the Vallon de St-Imier and Lake Biel (Fig. 6). The linear regression to the data points (Graph 1, Fig. 7) intersects the h-axis at $-2285 \mathrm{~m}$ (below the basal décollement), illustrating that neither a faultpropagation nor a detachment fold with a basal décollement horizon located in the Anhydritgruppe Formation, provide a viable solution (the graph should intersect the h-axis at zero). Rather, this diagram indicates that the graph-slope is too gentle due to reduced excess areas (compare Fig. 4c). We therefore propose a large-scale fault-bend fold, which is a common and well-established fold model to explain excess area loss (Suppe 1983; Mitra and Namson 1989; Epard and Groshong 1993). As previously mentioned, fault-bend folds have a ramp and an upper flat detachment (Fig. 4d). The unsmoothed depth grids (Engler and Sommaruga 2013) show a bending of the Mesozoic horizons underneath Lake Biel. Note that this bending is conceptual and results from interpolation in a zone that lacks data. The high dips from the outcrops of Base-Tertiary and Middle-Malm at the northern lakeshore need a bending in order to be linked with the low

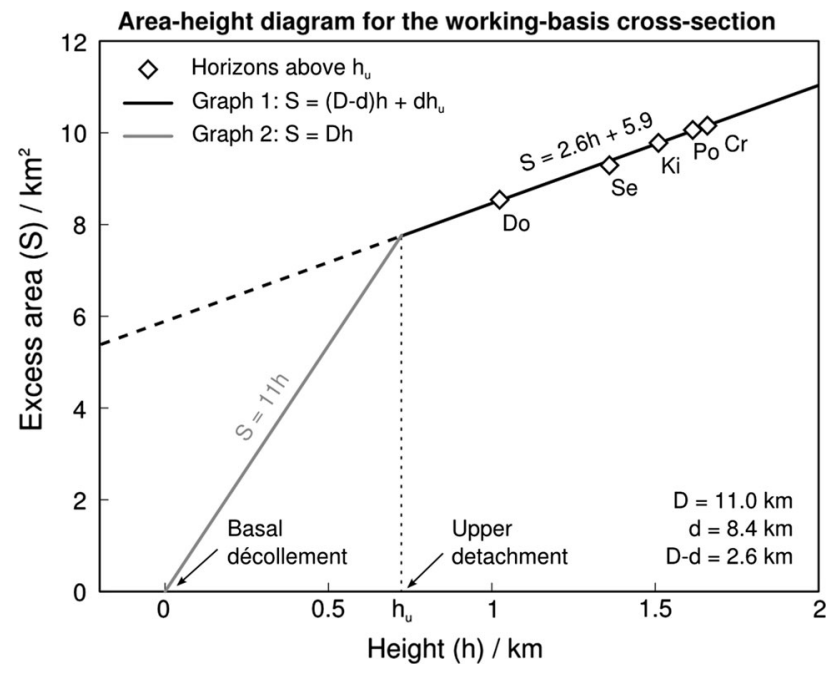

Fig. 7 Excess-area graphical construction for field-constrained horizons of the working basis cross-section. Top of Do Dogger, Se Séquanien, $\mathrm{Ki}$ Kimmeridgian, $\mathrm{Po}$ Portlandian, $\mathrm{Cr}$ Cretaceous sequence. $D$ total displacement, $d$ displacement across the section front, $h_{u}$ ramp height dips (confirmed by seismic data) underneath the Molasse plateau. The beginning of a ramp close to the St. Petersinsel (Fig. 6) is furthermore supported by extrapolation of seismic data at the shore of Lake Neuchâtel and the Tschugg area.

Mesozoic geological units beneath the Plateau de Diesse show significant regional structural uplift compared to the Molasse Basin (Fig. 6), and we propose that this uplift reflects the height of the upper detachment $\left(h_{u}\right)$, or rampheight respectively, in the evaluated fault-bend fold model. The ramp height is estimated at $700 \mathrm{~m}$, as is deduced from the structural uplift of Late Jurassic horizons at the Plateau de Diesse (Fig. 6). The Opalinus-Ton Formation, which consists of weak argillaceous rocks, is located $700 \mathrm{~m}$ above the defined basal décollement (Fig. 5), and at the same time provides favourable conditions for low-angle thrusts or detachments, respectively. This makes the Opalinus-Ton Formation a likely candidate for major detachments.

Moreover, there are direct indications for a tectonic uplift of the Vallon de St-Imier. A bedding dip of $8^{\circ}$ to the SSE suggests steepening due to tectonics. Furthermore, the BEA-line (Fig. 6) implies a dip of slightly more than $3^{\circ}$, which is steeper than the presumed basement dip of $2.5^{\circ}$. Taking into account these dips, the uplift of the Vallon de St-Imier is estimated to about $200 \mathrm{~m}$.

\subsection{Shortening estimates}

Assuming the location of the basal décollement in the Triassic evaporites and an upper detachment in the Opalinus-Ton Formation we constructed the area-height graph for horizons below the upper detachment (Fig. 7, Graph 2). Graph 1 is constructed from field-constrained horizons, whereas Graph 2 is fixed assuming that the basal décollement occurs in the Triassic evaporites and that the rampheight is $700 \mathrm{~m}$. The excess-area graphical technique thus allows an estimation of both the total displacement $\mathrm{D}=11.0 \mathrm{~km}$, and the displacement on the upper flat $\mathrm{d}=8.4 \mathrm{~km}$ (Table 1).

Table 1 Displacement and shortening estimates from field-constrained horizons of the working basis cross-section. The shortening of bed-length was calculated using the top of the Portlandian sequence

\begin{tabular}{lll}
\hline Distance & Method & Length $(\mathrm{km})$ \\
\hline Total displacement D & EA & 11.0 \\
Displacement d & EA & 8.4 \\
Displacement D-d & EA & 2.6 \\
Bed offset along thrusts & BL & 1.7 \\
Shortening from folded bed & BL & 2.6 \\
Total bed shortening & BL & 4.3
\end{tabular}

$E A$ estimate from excess-area comparison, $B L$ estimate from bedlength shortening, $D$ total displacement, $d$ displacement across the section front 
The top of the Portlandian sequence was used for a bedshortening estimate, because the Twannbach Formation, which was deposited during Portlandian times, is considered the best-documented lithological unit with many outcrops on the northern as well as on the southern Chasseral mountainside. It is furthermore an excellent keyhorizon, because the competent limestones show minimal tectonic thickness changes, which is important for conserving constant bed-length. Offsets of the top of the Portlandian sequence along thrusts and the straightened bed-segments are connected to a straight line. The length difference of $4.3 \mathrm{~km}$ between the obtained line and the BEA-line is considered as the total shortening by folding and thrusting in the working basis cross-section. The estimated offset along thrusts is $1.7 \mathrm{~km}$ and the shortening from folded bed-segments is $2.6 \mathrm{~km}$ (Table 1).

\section{Kinematic forward model}

\subsection{Thrust sequence}

The forward model (Fig. 8a-g) rests upon the evaluated structures at depth shown in Fig. 6, and respects a well-defined default structural style (Sect. 3.4.2). The lower ramp edge of the initial fault-bend fold roots in the Anhydritgruppe $\left(\mathrm{O}_{1}\right.$, Fig. $\left.8 \mathrm{~b}\right)$ and the dip of the ramp was set according to indications of the unsmoothed seismic grids (Engler and Sommaruga 2013) underneath Lake Biel. According to the forward model deformation concentrated to the NNW of the section $\left(\mathrm{P}_{1}\right.$ in Fig. $\left.8 \mathrm{~b}\right)$, translated along the upper detachment in the Opalinus-Ton Formation during a first stage. In this contribution deformation at $\mathrm{P}_{1}$ is not addressed, but we suggest that the backthrust of the Mont Soleil, north of the Vallon de St-Imier (Fig. 2), is possibly related to this first stage deformation. Thereby the proto Chasseral anticline forms as a simple fault-bend fold. Later, a thrust branches off at the upper ramp edge $\left(\mathrm{P}_{2}\right.$, Fig. $\left.8 \mathrm{c}\right)$ and leads to further development of the final Chasseral fault-propagation fold. Several fault-breakthroughs lead to a complex imbrication of the Chasseral anticline core and forelimb (Fig. 8c). A next fold forms forward propagating, above the upper detachment in the Opalinus-Ton Formation $\left(\mathrm{P}_{3}\right)$, and a low-angle breakthrough leads to a stair-step geometry of the thrust (Fig. 8d). In our model, the final thrust onto the Vallon de StImier again nucleates in the Opalinus-Ton $\left(\mathrm{P}_{4}, \mathrm{Fig}\right.$. 8e). Also this thrust is modelled to have a low-angle breakthrough, which leads to re-folding of older structures, as observed at the northern entry of the Combe Grède. The structure that has formed up to this point has to be displaced along the upper detachment for an additional $1.2 \mathrm{~km}$, thus increasing the distance $d$ and causing more deformation to the NNW of the section $\left(\mathrm{P}_{5}\right)$. In a next step, the Seekette anticline is formed
Fig. 8 Kinematic forward model of the Chasseral area. Branch points and outbreaks of thrusts are marked with red dots. $O$ outbreak in the basal décollement, $P$ branch point in the upper detachment, $D$ total displacement, $d$ displacement above the upper detachment across the frontal pin line

above a back-stepping backthrust that nucleates at the upper ramp edge of the large-scale fault-bend fold $\left(\mathrm{P}_{6}\right.$, Fig. 8f). The backthrust moves $200 \mathrm{~m}$ with the hanging wall to the NNW during its propagation and produces a wedge-structure. With the latter event, the deformation along the upper detachment terminates, and this upper detachment hence becomes inactive in the Chasseral area. During a last stage the activation of the basal décollement thickens the Triassic sequence by a ramp-fold and uplifts the northern Chasseral mountainside together with the Vallon de St-Imier (Fig. 8g).

The total displacement (D) of $11.3 \mathrm{~km}$ leads to a reasonably accurate correspondence between the model and the surface data. Out of this, a displacement of $5.1 \mathrm{~km}$ (Dd) is used to form the fault-propagation folds in the Chasseral area whereas $6.2 \mathrm{~km}$ are used to move material above the upper detachment across the frontal pin line, in order to form the proto Chasseral culmination and to eventually uplift the Vallon de St-Imier together with the northern Chasseral mountainside.

\subsection{Structural observations}

According to our forward model (Fig. 8), the Chasseral anticline formed by thrusting directly onto Cretaceous units, because there are no indications that Molasse sediments were involved in the thrusting of the Chasseral anticline, unlike in the Vallon de St-Imier where the Molasse sequence is found to be overthrust by Mesozoic units (Lüthi 1954; Della Valle et al. 1998). From the modelling we conclude that some bedding reflects the orientation of deep thrusts, such as underneath Lake Biel where it corresponds to the ramp of the initial fault-bend fold. Also, the lower part of the Chasseral-anticline backlimb is parallel to the thrust of the Chasseral fault-propagation fold, whereas the steepening of the upper backlimb reveals the position of the branch point belonging to the subsequent fault-propagation fold (see branch bisector trajectories Fig. 9).

\section{Discussion}

\subsection{Forward model}

\subsubsection{Structural observations}

Using trishear to model folds produces considerable thickness variations of beds that initially had a constant 
(a) Initial bedding at a constant thickness

(b) Proto Chasseral culmination ( $D=3.9 \mathrm{~km}, \mathrm{~d}=3.9 \mathrm{~km})$

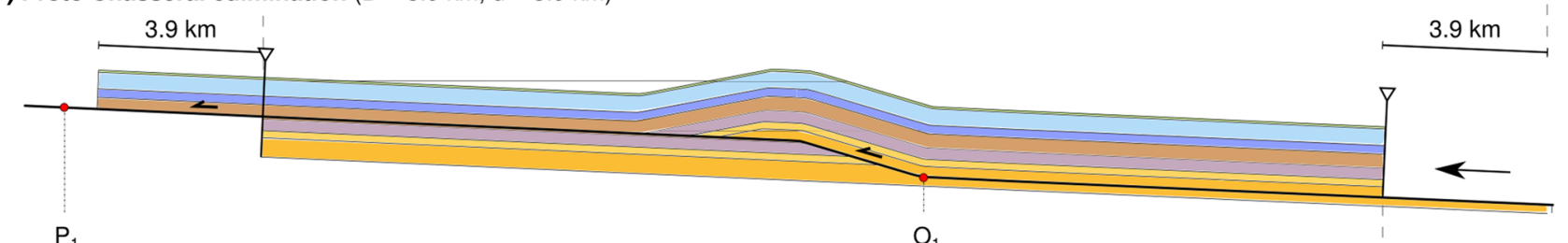

(c) Chasseral fault-propagation fold with several breakthroughs $(D=5.6 \mathrm{~km}, d=3.9 \mathrm{~km})$

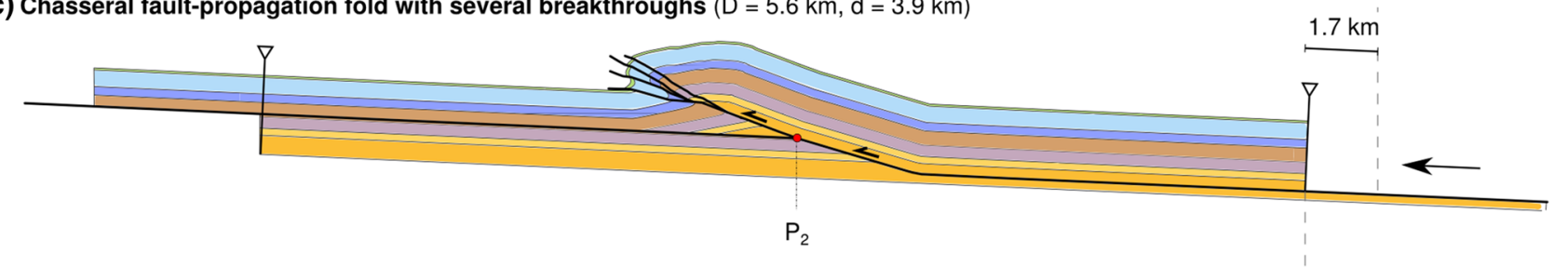

(d) Next fault-propagation fold with low-angle breakthrough $(\mathrm{D}=7.7 \mathrm{~km}, \mathrm{~d}=3.9 \mathrm{~km})$

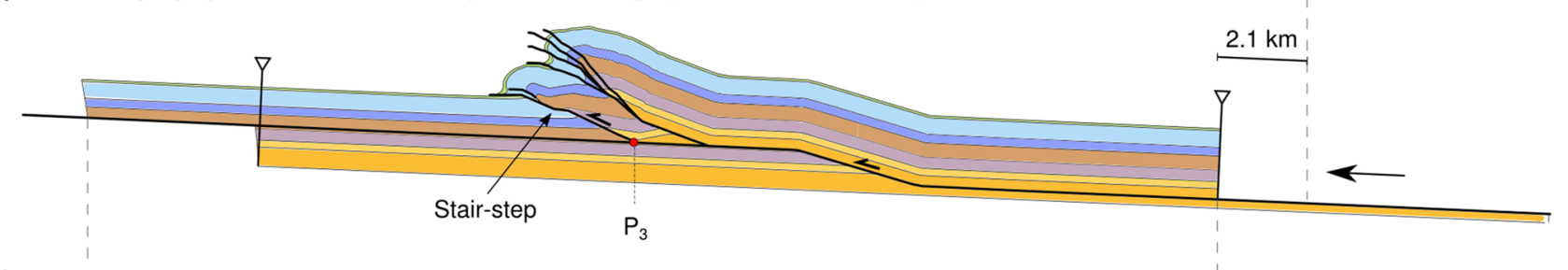

(e) Overthrust of Vallon de St-Imier, additional reactivation of upper detachment ( $D=10.0 \mathrm{~km}, \mathrm{~d}=5.1 \mathrm{~km})$

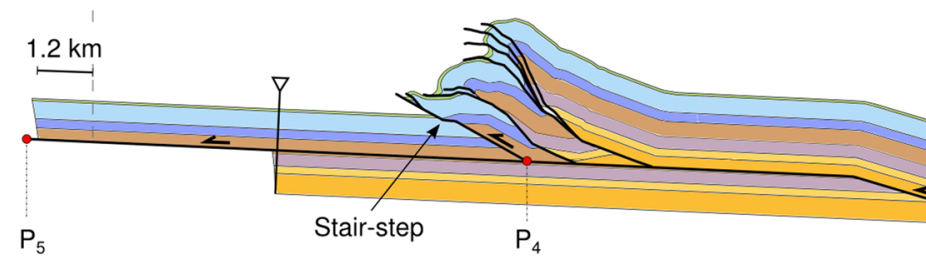

(f) Seekette wedge $(D=10.2 \mathrm{~km}, \mathrm{~d}=5.1 \mathrm{~km})$

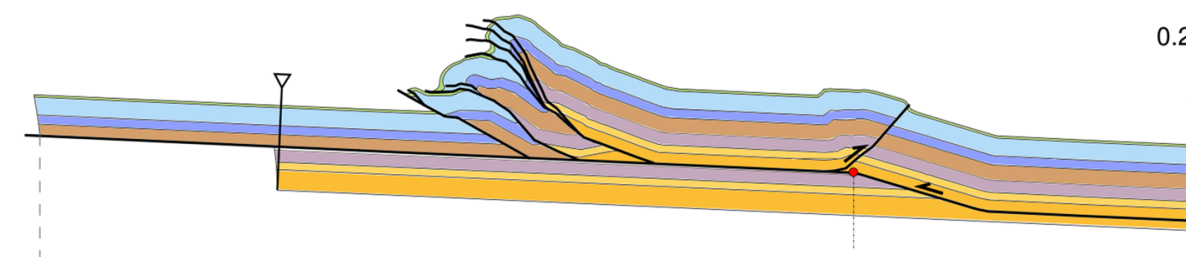

(g) Continuation of basal décollement

$P_{6}$

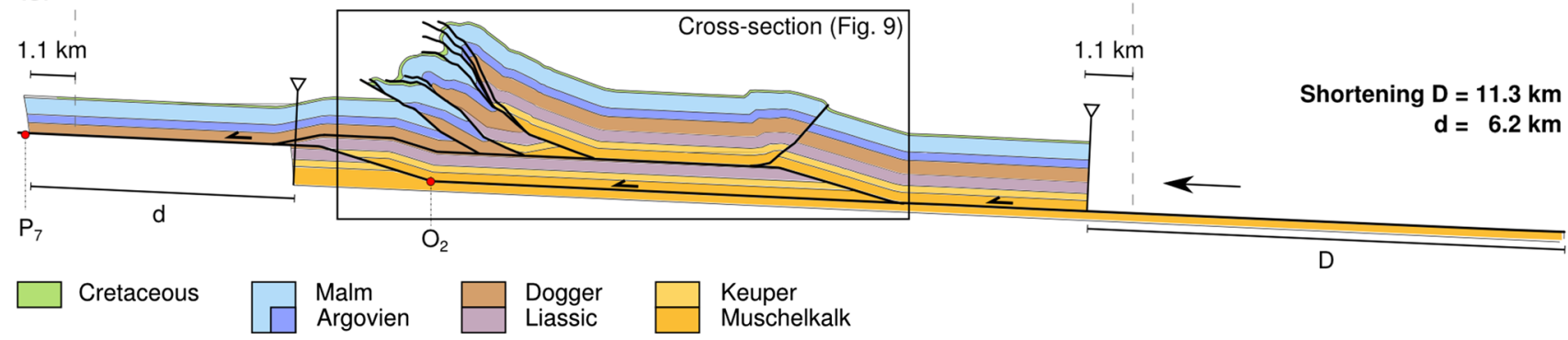




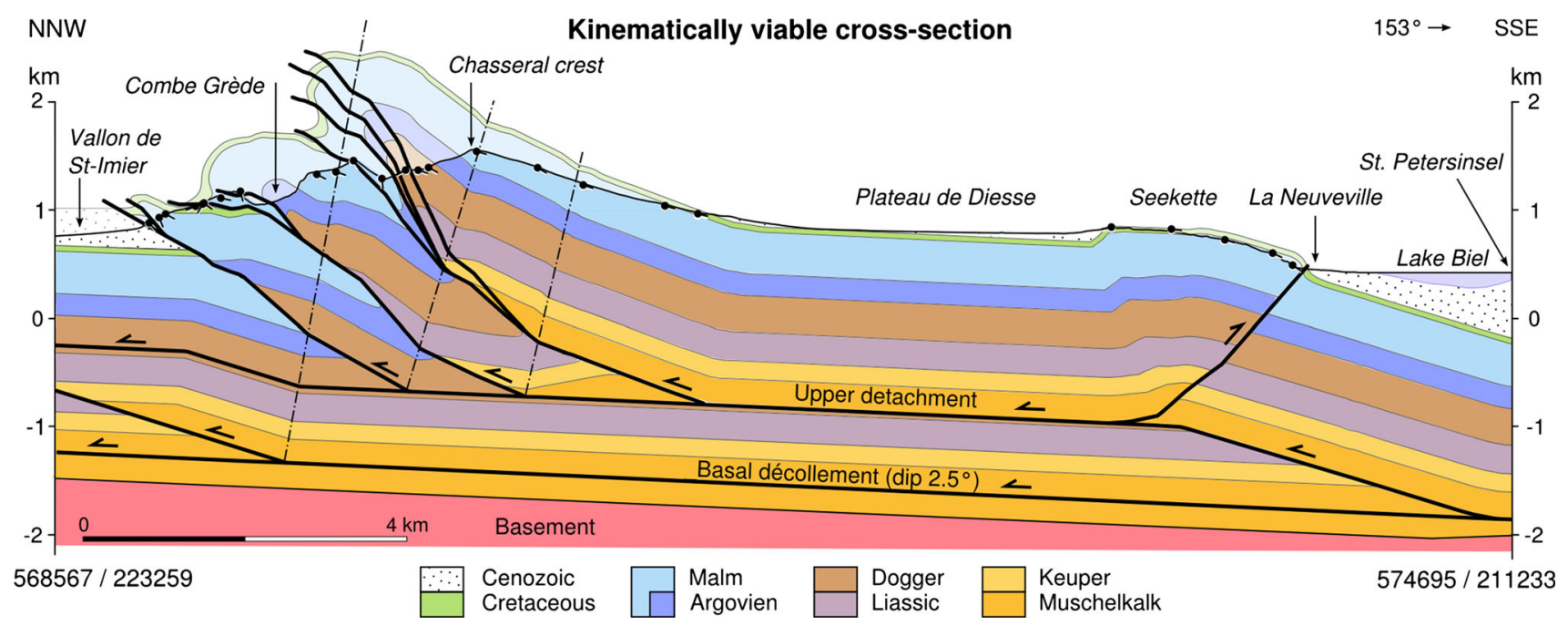

Fig. 9 Forward modelled cross-section of the Chasseral area. Some branch bisector trajectories, that acted as flow deflector lines used by the fault-parallel flow method, are illustrated with dot-dashed lines.

thickness. These thickness changes indicate zones of penetrative strain whereby this strain may be accommodated by various processes, depending on the lithology (Allmendinger 1998). During field investigations at the northern Chasseral mountainside, we observed intense fracturing but constant thicknesses of competent limestone units within high-strain zones whereas incompetent marl units (although usually hidden by Quaternary sediments and vegetation) showed notable thickness changes. The incompetent units, which reveal the highest thickness changes, belong to the Argovien sequence (Lüthi 1954). Tectonic thickness change due to penetrative strain is furthermore expected within the Aalenian shales and the Triassic evaporites.

It remains particularly difficult to interpret the extent of eroded fold-portions without a kinematic model. For example, the core of the Chasseral anticline is affected by several thrusts, which makes the interpretation of stratigraphic dips quite complex. As a result, the geometry of the Chasseral anticline in the working basis cross-section (Fig. 6) deviates from the kinematically viable version (Fig. 9), suggesting that its amplitude was initially underestimated.

Final low-angle thrust-breakthroughs in the Malm limestones are thought to occur in a "mature" stage of fault-propagation folds ultimately leading to stair-step geometries of thrust planes.

\subsubsection{Inferences on the sequence of thrusting}

Improbable branch-point positions were discernible by forward modelling and simultaneous monitoring of certain broader key structures. The backlimb of the Chasseral
Note that the short wavelength folds at the northern Chasseral mountainside are not modelled in detail

anticline indicated improbable frontal structures by adopting geometries that are not observed in reality, such as distinct kinks or very steep beds. It is seen for example, that the folds north of the Chasseral anticline are unlikely to root in the Triassic evaporites, because the forward models illustrated that frontal fault-propagation folds nucleating in the basal décollement lead to an oversized Chasseral anticline. Furthermore, we assess that the northern Chasseral mountainside requires a break-forward sequence of thrusting, with thrusts that produce faultpropagation folds and eventually refold previous structures. In respect to the northern Chasseral mountainside, the Seekette appears to have formed due to a late backthrust, because an early formation above the upper detachment would otherwise have caused the Seekette to move far to the NNW. However, the forward model supports a general forward propagation of the basal décollement from SSE to NNW in the Chasseral area, even though structures above the upper detachment indicate a more complex oscillating thrust sequence (Fig. 8).

Some observed open synclines are suggested to be indicative for branch-points of thrusts leading to subsequent fault-propagation folds during foreland-propagating deformation of the northern Chasseral mountainside. The presented forward model illustrates that basically two types of synclines can be distinguished in relation to the timing of their formation. The first type comprises primary synclines in the forelimb and backlimb of fault-propagation folds (Fig. 10a). They are directly connected to the faultpropagation fold, which they constitute. The forelimbsynclines may show breakthrough thrusts with overturned hanging walls, whereas backlimb related synclines are open folds. A second type of syncline develops as a 
(a)

(b)
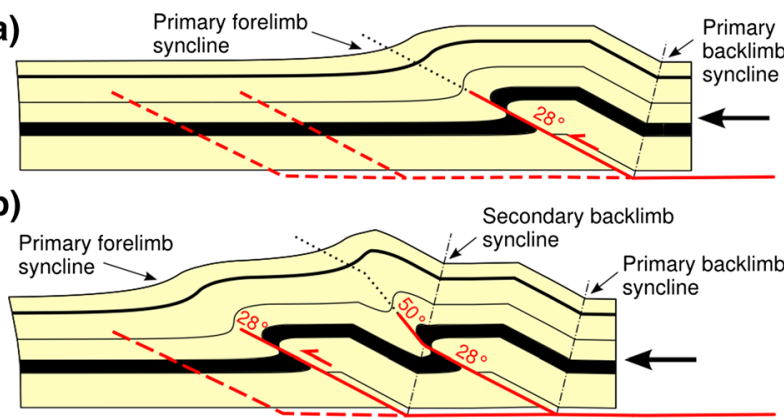

(c)

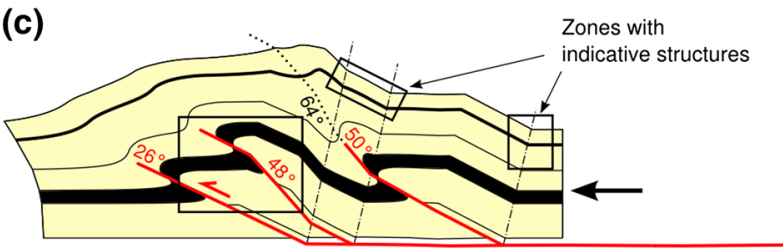

Fig. 10 Illustration of deformation structures during an in-sequence formation of fault-propagation folds with blind thrusts. The example is forward modelled using the trishear kinematic model, combined with the fault-parallel flow method for deformation outside of the trishear zone. Ramp bisector trajectories are indicated with dotdashed lines. a The first fold forms along a thrust with a dip of $28^{\circ}$. b The second fold refolds the former structure producing a secondary syncline and a part of the former thrust that is passively steepened to a dip of $50^{\circ}$. Note that only material which progressed across the bisector trajectory is refolded. c The third fault-propagation fold increasingly steepens and refolds both former structures. Zones are indicated, which contain important indicative tectonic structures

syncline that is related to re-folding of folds by younger frontal fault-propagation folds, and it may bear resemblance to a primary backlimb syncline at the surface (Fig. 10b). Horizontal structures that move across branch bisectors of frontal thrusts become inclined to the hinterland (Fig. 10b). The amount of branch points that were passed is mirrored in an increasing steepness of structures. The presented forward model across the Chasseral area operates with foreland-verging main thrusts active at SSEdips between 22 and $30^{\circ}$ (Fig. 8). Thrusts that are steeper have been passively tilted into steeper positions. Thus, thrusts with a dip of $40^{\circ}-52^{\circ}$ progressed past one branch bisector trajectory (Fig. 10b), and thrusts with a dip of more than $55^{\circ}$ passed a second bisector trajectory (Fig. 10c).

\subsection{Excess-area graphical construction}

\subsubsection{Tectonic uplift of Vallon St-Imier}

The excess-area graphical technique was applied to the working basis cross-section using horizons underneath the Vallon de St-Imier as reference levels for the BEA-line construction, although there is strong evidence that the Vallon de St-Imier is tectonically uplifted (Sect. 5.2). As a consequence, displacement estimates from excess area

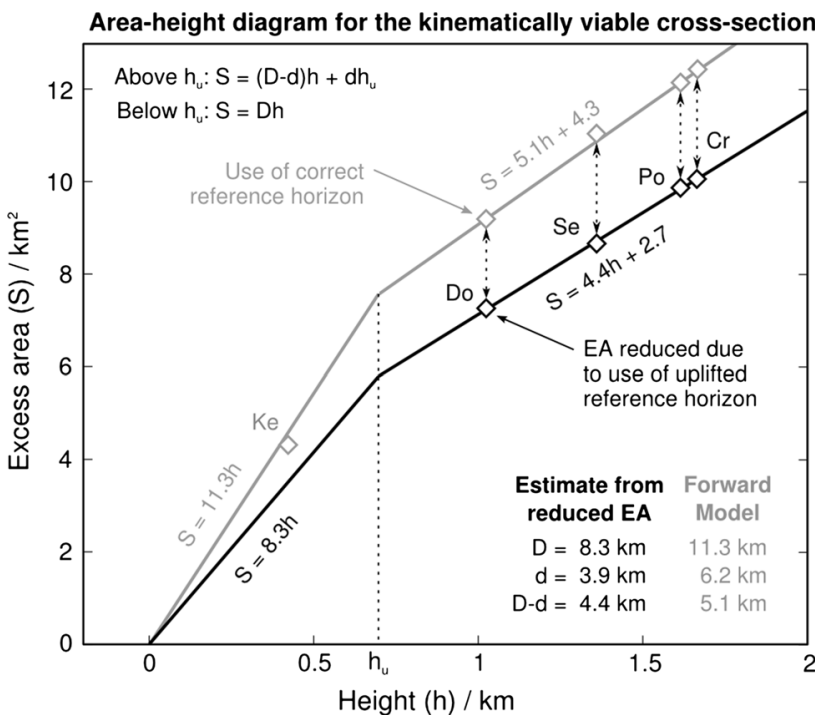

Fig. 11 Area-height diagram for the kinematically viable crosssection (Figs. 8, 9). The black graph is constructed by using uplifted reference horizons in the Vallon de St-Imier, whereas the grey graph is based on correct reference horizons. The deviation between the two graphs illustrates the error due to the use of uplifted reference horizons. $E A$ excess area, $D$ total displacement, $d$ displacement on the upper detachment, $h_{u}$ height of upper detachment, $\mathrm{Cr}$ top Cretaceous, Po top Portlandian, Se top Séquanien, Do top Dogger, Ke top Keuper sequence

comparison are distorted. In order to estimate the error, the Chasseral area forward model was analysed with the excess-area graphical technique, assuming the same BEAlines as used for analysing the working basis section. It is seen that using uplifted horizons as reference levels for BEA-lines produces reduced excess areas that eventually lead to a smaller total displacement D (Fig. 11). The underestimate for the presented forward model, using uplifted horizons of the Vallon de St-Imier, is $3 \mathrm{~km}$ (with $\mathrm{D}_{\text {model }}=11.3 \mathrm{~km}$ and $\mathrm{D}_{\text {EA-estimate }}=8.3 \mathrm{~km}$, Fig. 11).

\subsubsection{Improving the interpretation of area-height diagrams}

The analysis of excess areas indicates that not all displacement along the upper detachment formed structures within the Chasseral area, but also further to the NNW in respect to the section. We propose that the shortening inferred from bed-length in the Chasseral area, indicates the displacement that is needed to form the folds and thrusts in the Chasseral area only. Put another way, the shortening from bed-length indicates the total displacement, excluding hidden displacement above the upper detachment (D-d). This can be tested in the presented forward model. The line-length shortening of the top of the Portlandian sequence is estimated at $5.1 \mathrm{~km}$, which is in agreement with the effectively modelled distance D-d 
(11.3-6.2 km). Hence we conclude that shortening obtained from bed-length analysis in the Chasseral area is indicative for the slope of the excess area graph for horizons above the upper detachment (Fig. 11).

We use this finding to analyse the working basis crosssection (Fig. 6). The slope of the graph for horizons above the upper detachment (corresponding to D-d), from fieldconstrained horizons of the working basis cross-section, was constructed at $2.6 \mathrm{~km}$, whereas line-length shortening of the top Portlandian sequence revealed $4.3 \mathrm{~km}$ (Table 1). The significant difference of shortening estimates between the bed-length method and the excess-area comparison method points to uncertainties in the construction of the working basis section. These uncertainties concern exact offset along thrusts, extent of the Chasseral anticline above surface and the use of the structurally uplifted Vallon de StImier for constructing the BEA-lines. Note that the distance D-d of $4.3 \mathrm{~km}$, estimated from bed-length shortening, is in better agreement with the excess area plot of the kinematically viable cross-section (Fig. 11).

\subsection{Consequences of the presented structural style}

Our forward modelling proposes a fault-bend fold with a large displacement along an upper detachment located in the Opalinus-Ton Formation that results from thin-skinned deformation of the Jura. Hence, our model does not require thick-skinned involvement of the basement.

The branch bisector trajectory belonging to the lower ramp edge of the large-scale fault-bend fold cuts the surface at the St. Petersinsel. Although further investigation is beyond the scope of this contribution we wish to point out that the branch bisector trajectory is an important zone of brittle deformation, which may have predetermined the incision of glaciers. The reason for the nucleation of the first thrust at the Chasseral, and thus the first appearance of a culmination, may be either linked to inherited structures in the Mesozoic cover (e.g. palaeofaults) or to the basement morphology. Considering structures in the basement as a trigger, it is doubtful that the nucleation point would lie underneath Lake Biel. According to Burkhard (1990) the shortening of the Central Jura is in excess of $25 \mathrm{~km}$. Given the shortening of $\sim 11 \mathrm{~km}$ proposed by our Chasseral forward model, the initial outbreak of the thrust may have occurred as far as $14 \mathrm{~km}$ (shortening of the Central Jura minus shortening of the Chasseral area) to the SSE of the present position, depending on the thrust-sequence of the basal décollement.

The presented forward model opens scope for additional work. A consequence of our model would be that the deformation to the north of the Chasseral area is the result of a complex series of thrusts above an upper detachment, interacting with thrusts that nucleate in the basal décollement. The kinematically viable cross-section (Fig. 9) shows that material is moved along different detachments or thrusts across the NNW boundary of the section. Consequently, new solutions regarding the deformation north of the Chasseral area need to be found in the future in support of our model. More precise estimates of the total displacement in the Chasseral area need to include the entire central part of the Internal Jura north of the Vallon de St-Imier. High-seated anticlines found elsewhere require investigations regarding detachment levels in higher stratigraphic levels in order to discern between regions with basement highs resulting from a thick-skinned component and regions where only the Mesozoic sequence is tectonically thickened. The individual deformational style of the Middle Triassic to Liassic package in the Central Jura fold-and-thrust belt should be reinvestigated and geophysical data should be consulted for e.g. depth to magnetic basement, gravity modelling and seismic lines.

\section{Conclusions}

A purely thin-skinned deformation style in the Jura Mountains is able to produce regional structural uplift. This has important consequences on the interpretation of the Chasseral area and to the Central Jura Mountains at a larger scale. In addition to the classical basal décollement in the Triassic evaporites, we provide evidence for the existence of an upper detachment horizon in the Opalinus-Ton Formation that may play a key role in the structural development of parts of the Jura fold-and-thrust belt. We propose a sequential kinematic model that combines the development of fault-bend folds and complex fault-propagations folds in break-forward sequences and in backstepping thrusts, which sheds new light on the evolution of the Central Jura Mountains. Regarding the Chasseral area in particular we conclude that:

1. The Chasseral structure is considered a fault-bend fold with field-constrained horizons that indicate a loss of excess area above an upper detachment. In our model, an initial thrust ramps up from the basal décollement and develops into a fault-bend fold, before faultpropagation folds above the upper detachment start to form the present-day structures in the Chasseral area. Interaction of deformation above the upper detachment level with the basal décollement level leads to complex structures NNW of the Chasseral area. Our forward model reveals a total shortening of $11.3 \mathrm{~km}$, whereby only $5.1 \mathrm{~km}$ are needed to form the fault-propagation folds in the Chasseral area.

2. Regional tectonic uplift in the Central Jura is seen as a consequence of thrusting along an upper detachment 
horizon, causing substantial thrust related thickening of the Mesozoic sequence. This structural style satisfactorily explains tectonic uplifts of some $200 \mathrm{~m}$ of the Vallon de St-Imier and $700 \mathrm{~m}$ of the Plateau de Diesse. We suggest that the Opalinus-Ton Formation played a key role during the formation of uplifted plateaus in the Central Jura, since it potentially hosts an upper detachment.

3. The forward-model indicates a complex thrust sequence above the upper detachment. Initially, deformation extends to the north of the Chasseral area and steps back later to form a series of forward-stepping thrusts at the northern Chasseral mountainside, that develop into fault-propagation folds. These thrusts show a typical stair-step geometry due to low-angle breakthroughs. Finally, the Seekette anticline on the southern Chasseral mountainside forms due to a backstepping backthrust. The thrust-sequence of the basal décollement in the Chasseral area is forward propagating in contrast to the thrust-sequence on the upper detachment.

Acknowledgments The authors are indebted to M. Gruber (Fribourg) and A. Sommaruga (Fribourg) for many stimulating discussions. We would like to thank M. Gruber for providing well-data and seismic depth grids from his extensive database of the Molasse Basin, A. Malard and D. Rickerl (La Chaux-de-Fonds) for providing insight into their model of the Chasseral and St-Imier valley, C. Isenschmid (Bern) for providing access to reports about geological investigations in the Vallon de St-Imier and swisstopo for generously publishing valuable geological data. The review of the early manuscript by A. Sommaruga improved the introduction greatly and we acknowledge the constructive remarks. Thanks are extended to the reviewers U. Eichenberger and J. Kley, as well as to the editor S. Schmid, who all helped to improve the manuscript substantially. We gratefully acknowledge Midland Valley for providing the software MOVE which made the kinematic analysis possible and thanks are extended to the University of Fribourg and the University of Bern for financial support.

\section{References}

Affolter, T. (2003). Étude des déformations et restaurations 3D d'un bassin de front de chaîne: l'exemple du Jura et des massifs Subalpins français. Thèse, Université Grenoble, pp. 28-92.

Allmendinger, R. W. (1998). Inverse and forward numerical modeling of trishear fault-propagation folds. Tectonics, 17, 640-656.

Becker, A. (2000). The Jura Mountains - an active foreland fold-andthrust belt? Tectonophysics, 321, 381-406.

Bitterli, T. (1992). Die Anwendung der tektonischen Materialbilanz im östlichen Faltenjura. Inauguraldissertation, Universität Basel, pp. $15-28$.

Burkhard, M. (1990). Aspects of the large-scale Miocene deformation in the most external part of the Swiss Alps (Subalpine Molasse to Jura fold belt). Eclogae Geologicae Helvetiae, 83, 559-583.

Buxtorf, A. (1907). Zur Tektonik des Kettenjura. Berichte über die Versammlungen des Oberrheinischen geologischen Vereins, 40, 79-111.
Buxtorf, A. (1916). Prognosen und Befunde beim Hauensteinbasisund Grenchenbergtunnel und die Bedeutung der letzteren für die Geologie des Juragebirges. Verhandlungen der Naturforschenden Gesellschaft in Basel, 27, 184-254.

Chamberlin, R. T. (1910). The Appalachian folds of central Pennsylvania. Journal of Geology, 18, 228-251.

Chamberlin, R. T. (1919). The building of the Colorado Rockies. Journal of Geology, 27, 225-251.

Della Valle, G., Rieben, C., Adatte, P. (1998). Prospection d'eau souterraine par forages profonds dans le Vallon de St-Imier. Technical report, Office de l'Economie Hydraulique et Energétique du Canton du Berne (OEHE), pp. 21-51.

Egan, S.S., Buddin, T.S., Kane, S., Williams, G.D. (1997). Threedimensional modelling and visualisation in structural geology: New techniques for the restoration and balancing of volumes. In: Proceedings of the 1996 Geoscience Information Group Conference on Geological Visualisation (pp. 67-82). Electronic Geology.

Engler, R., \& Sommaruga, A. (2013). User guide to the methodology of the Seismic Atlas of the Swiss Molasse Basin. Report and GIS database for swisstopo, Université de Fribourg, unpublished.

Epard, J. L., \& Groshong, R. H. J. (1993). Excess area and depth to detachment. The American Association of Petroleum Geologists Bulletin, 77(8), 1291-1302.

Erslev, E. A. (1991). Trishear fault-propagation folding. Geology, 19, 617-620.

Fischer, H., \& Luterbacher, H. (1963). Das Mesozoikum der Bohrungen Courtion 1 (Kt. Fribourg) und Altishofen 1 (Kt. Luzern). Beiträge zur Geologischen Karte der Schweiz, 115, 32-40.

Fornage, P. (1983). Rapport geologique final du sondage Hermrigen 1D. Report, Office de l'Economie Hydraulique et Energétique du Canton du Berne.

Guellec, S., Mugnier, J., Tardy, M., \& Roure, F. (1990). Neogene evolution of the western Alpine foreland in the light of ECORS data and balanced cross sections. In F. Roure, P. Heitzmann, \& R. Polino (Eds.), Deep structure of the Alps (pp. 165-184). Zurich: Mémoires de la Société géologique suisse.

Housse, B.A. (1982). Forage Hermrigen-1, Informations intéressant la Géothermie recuillies au cours du forage et des essais. Report, Office de l'Economie Hydraulique et Energétique du Canton du Berne, unpublished report.

Jordan, P. (1992). Evidence for large-scale decoupling in the Triassic evaporites of Northern Switzerland: an overview. Eclogae Geologicae Helvetiae, 85(3), 677-693.

Kane, S.J., Williams, G.D., Buddin, T.S., Egan, S.S., Hodgetts, D. (1997). Flexural-slip based restoration in 3D, a new approach. 1997 AAPG Annual Convention Official Program, A58.

Laubscher, H. P. (1961). Die Fernschubhypothese der Jurafaltung. Eclogae Geologicae Helvetiae, 54, 221-281.

Laubscher, H. P. (1965). Ein kinematisches Modell der Jurafaltung. Eclogae Geologicae Helvetiae, 58, 232-318.

Laubscher, H. P. (1986). The Eastern Jura-relations between thinskinned and basement tectonics, local and regional. Geologische Rundschau, 75, 535-553.

Laubscher, H. (1992). Jura kinematics and the Molasse Basin. Eclogae Geologicae Helvetiae, 85(3), 653-675.

Laubscher, H. (2003). Balanced sections and the propagation of décollement: a Jura perspective. Tectonics. doi:10.1029/ 2002 TC001427.

Laubscher, H. (2008). The Grenchenberg conundrum in the Swiss Jura: a case for the centenary of the thin-skin décollement nappe model (Buxtorf 1907). Swiss Journal of Geosciences, 101, 41-60.

Lüthi, E. (1954). Geologische Untersuchungen im Gebiete zwischen Tessenberg und St.Immertal (Berner Jura). Promotionsarbeit, Eidgenössische technische Hochschule Zürich, pp. 9-37. 
Madritsch, H., Schmid, S. M., \& Fabbri, O. (2008). Interactions between thin- and thick-skinned tectonics at the northwestern front of the Jura fold-and-thrust belt (eastern France). Tectonics. doi:10.1029/2008TC002282.

Mitra, S., \& Namson, J. (1989). Equal-area balancing. American Journal of Science, 289, 563-599.

Mosar, J. (1999). Present-day and future tectonic underplating in the western Swiss Alps : reconciliation of basement wrench-faulting and décollement folding of the Jura and Molasse basin in the Alpine foreland. Earth and Planetary Science Letters, 173, 143-155.

Mosar, J., Ibele, T., Matzenauer, E. (2008). Tectonics of the Molasse Basin of Western Switzerland: an overview. Nagra Arbeitsbericht NAB 08-07, pp. 84.

Noack, T. (1995). Thrust development in the eastern Jura Mountains related to pre-existing extensional structures. Tectonophysics, 252, 419-431. doi:10.1016/0040-1951(95)00089-5.

Persoz, F., \& Burkhard, M. (2006). Histoire géologique de la région de Lignières. In Lignière, Un village aux confins de trois Etats (pp. 11-18), Editions Gilles Attinger SA Hauterive, Suisse.

Pfiffner, O., Erard, P. F., \& Stäuble, M. (1997). Two cross sections through the Swiss Molasse Basin (line E4-E6, W1, W7, W10). In O. A. Pfiffner, P. Lehner, P. Heitzmann, S. Müller, \& A. Steck (Eds.), Deep structure of the Swiss Alps, results of NRP 20 (pp. 64-72). Basel: Birkhäuser Verlag.

Philippe, Y. (1995). Rampes latérales et zones de transfert dans les chaînes plissées: Géométrie, conditions de formation et pièges structuraux associés. Thèse de Doctorat, Université de Savoie.

Schär, U., Ryniker, K., Schmid, K., Häfeli, Ch., Rutsch, R.F. (1971). Bieler See (LK1145). Geologischer Atlas der Schweiz 1:25'000, Federal Office of Topography swisstopo.

Schlanke, S., Hauber, L., \& Büchi, U. P. (1978). Lithostratigraphie und Sedimentpetrographie der Molasse in den Bohrungen Tschugg I und Ruppoldsried I (Berner Seeland). Eclogae Geologicae Helvetiae, 71(2), 409-425.

Schori, M. (2014). Combined structural field investigations and remote sensing analysis of the Combe Grède area (Chasseral, Central Jura). Masterarbeit, Universität Bern, unpublished, pp. 56-71.
Smit, J. H. W., Brun, J. P., \& Sokoutis, D. (2003). Deformation of brittle-ductile thrust wedges in experiments and nature. Journal of Geophysical Research. doi:10.1029/2002JB002190.

Sommaruga, A. (1997). Geology of the Central Jura and the Molasse Basin: new insight into an evaporite-based foreland fold and thrust belt. Mémoire de la société Neuchâteloise des Sciences Naturelles, Université de Neuchâtel, pp. 75.

Sommaruga, A. (1999). Décollement tectonics in the Jura foreland fold-and-thrust belt. Marine and Petroleum Geology, 16, 111-134.

Sommaruga, A., Eichenberger, U., Marillier, F. (2012). Seismic Atlas of the Molasse Basin. In E. Kissling (Ed.), Beiträge zur Geologie der Schweiz-Geophysik (pp. 64), Federal Office of Topography swisstopo.

Suppe, J. (1983). Geometry and kinematics of fault-bend folding. American Journal of Science, 283, 684-721.

Suppe, J., \& Medwedeff, D. A. (1990). Geometry and kinematics of fault-propagation folding. Eclogae Geologicae Helvetiae, 83(3), 409-454.

Swisstopo (2005). Tektonische Karte der Schweiz 1: 500 000. Federal Office of Topography swisstopo.

Swisstopo (2011). Digital elevation model swissALTI3D. Federal Office of Topography swisstopo.

Swisstopo (2012). GeoCover-geological vector data. Federal Office of Topography swisstopo.

Thurry, M., \& Amman, M. (1990). Les sept forages de la Cédra dans le nord de la Suisse. Cédra Informe, 2, 7-15.

Ustaszewski, K., \& Schmid, S. M. (2006). Control of preexisting faults on geometry and kinematics in the northernmost part of the Jura fold-and-thrust belt. Tectonics. doi:10.1029/ 2005 TC001915.

Ustaszewski, K., \& Schmid, S. M. (2007). Latest Pliocene to recent thick-skinned tectonics at the Upper Rhine Graben-Jura Mountains junction. Swiss Journal of Geosciences, 100, 293-312.

Winnock, E. (1961). Résultats géologiques du forage Risoux 1. Bulletin der Vereinigung Schweizerischer Petroleum-Geologen und Ingenieure, 28, 17-26. 